\title{
Cost of Equity Estimation in Fuel and Energy Sector Companies Based on CAPM
}

\author{
Diana Kozieł ${ }^{1}$, Stanisław Pawłowski ${ }^{1}$, and Arkadiusz Kustra ${ }^{1, *}$ \\ ${ }^{1}$ AGH University Science and Technology, Faculty of Mining and Geoengineering, \\ A. Mickiewicza Av. 30, 30-059 Krakow, Poland
}

\begin{abstract}
The article presents cost of equity estimation of capital groups from the fuel and energy sector, listed at the Warsaw Stock Exchange, based on the Capital Asset Pricing Model (CAPM). The objective of the article was to perform a valuation of equity with the application of CAPM, based on actual financial data and stock exchange data and to carry out a sensitivity analysis of such cost, depending on the financing structure of the entity. The objective of the article formulated in this manner has determined its' structure. It focuses on presentation of substantive analyses related to the core of equity and methods of estimating its' costs, with special attention given to the CAPM. In the practical section, estimation of cost was performed according to the CAPM methodology, based on the example of leading fuel and energy companies, such as Tauron GE and PGE. Simultaneously, sensitivity analysis of such cost was performed depending on the structure of financing the company's operation. Key words - cost of equity, fuel and energy sector.
\end{abstract}

\section{Introduction}

An accurate estimation of the cost of equity in capital groups of the fuel and energy sector is an important issue, due to the fact that in reference to extraction or production, equity is often the only available source of capital. Such situation is particularly common in mining companies in the initial stages of life cycle of an extraction project, thence at the stage of geological studies and deposit prospection, characterised by greatest risk and therefore difficulties in procuring external sources of financing.

Accuracy in equity assessment influences the weighted-average cost of capital (WACC), which translates to greater precision of estimates of such aspects as the value of the enterprise or economic efficiency of an investment.

An important aspect of estimating the cost of equity is its' changeability depending on the share in the financing structure.

In the context of significance of precise estimation of the cost of equity, the objective of the article is to present the methods of estimating such cost with special attention given to the CAPM and to estimate the cost of equity of two companies from the fuel and energy sector listed on the WSE, along with presentation of variability of the cost of equity as a function of share of this type of capital in the financing structure.

* Corresponding author: kustra@agh.edu.pl 


\section{Cost of Equity and Methods of Its' Estimation}

The cost of equity may be identified with the rate of return expected by the owners of equity from funds invested in the company. When estimating the cost of equity, it is necessary to rely on indirect methods, based on the evaluation of investors' expectations.

An additional difficulty in estimating this value is the fact that the cost of equity is not neutral in the light of changing debt, which makes it grow along with the growth of the level of use of borrowed capital and, therefore, the financial risk. [6]

The equity in a company includes:

- entrusted capital (funds): these are the original financial or material contributions of owners, made at the moment of establishing an economic entity and they can be supplemented (increased) later;

- self-financing capital (funds): they originate from the accomplished profit retained in the company or from other sources characteristic for a given type of activity.

Therefore, it is possible to distinguish two sources of origin of equity:

- capital procured via issue of new shares;

- capital procured via retaining profit generated in the company.

The issue of shares is related to incurring costs connected with fees and commissions, preparation of an issue prospectus and, frequently, with sale of shares below their nominal value.

In the case of profit generated by a company, costs are related to the taxation. In multiple countries there is double taxation consisting in the fact that a company has to pay income tax on the generated gross profit, whereas shareholders once again pay a tax on the received dividend, which derives from the already taxed profit. Retaining a generated profit in the company therefore results in reduction of the cost of equity on account of no costs of a new issue and, on the other, no double taxation. Due to this, the cost of equity deriving from reinvestment of generated profits is lower than the cost of equity procured from a new issue of shares.

Literature on the subject presents three main methods of determining the cost of equity.

- Dividend models (e.g. Gordon Growth Model),

- Compounding interest rate models (e.g. the Bond Plus Model),

- CAPM.

\section{Estimation of equity cost according to CAPM methodology}

The structure of the CAPM brings to mind the method of risk free rate increased by a premium for market risk; however, the important difference is the presence of beta $(\beta)$ factor in the method. It is assumed in the CAPM that the market risk is the only source of risk influencing long-term average rates of return from equity. Beta is the measure of such risk. Its' value shows the degree in which changes of share rates of analysed company are related to changes in the rates of market portfolio (in the Polish conditions, the WIG index).

The value of beta depends on three factors: the area of business in which the company is conducting its' operation, the operational leverage and the financial leverage. In practice, $\beta$ may assume the following values [9]:

- $\boldsymbol{\beta}=\mathbf{1}$, which means that the pace of changes of the rate of return from investment in assets of a given company is exactly the same as the pace of changes of the rate of return from the market portfolio;

- $\quad \mathbf{0}<\boldsymbol{\beta}<1$, which means that the rate of return of the company's assets is changing slower than the rate of return from the market portfolio, which means smaller risk of investing in the equity of a given company than in market instruments; 
- $\boldsymbol{\beta}>\mathbf{1}$, which means that the pace of changes of the rate of return from investment in assets of a given company is greater than the pace of changes of the rate of return from the market portfolio;

$-\quad \boldsymbol{\beta}<\mathbf{0}$, which means that the rate of return from investment in assets of a given company is reversely proportional to the rate of return from the market portfolio - if the market rate grows, the value of shares of the analysed company drops and vice versa.

Graphic interpretation of beta is presented in Figure 1.

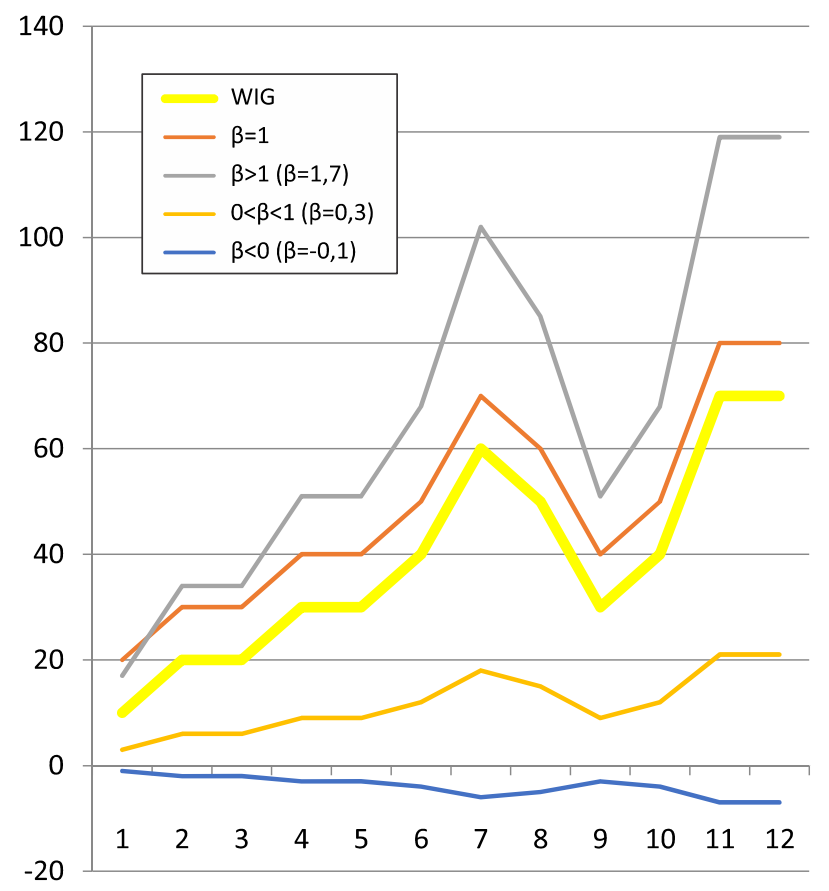

Fig. 1. Graphic interpretation of $\beta$ factor

Calculation of $\beta$ is made on the basis of the formula:

$$
\beta_{E}=\frac{\operatorname{cov}\left(r_{E}, r_{W I G}\right)}{\operatorname{var} r_{W I G}}
$$

where:

$r_{E}$ - rate of return from shares of the analysed company;

$r_{W I G}-$ rate of return from the market portfolio.

Cost of equity in the CAPM is determined on the basis of the following formula:

$$
r_{E}=r_{A W R}+\beta_{E} \cdot\left(r_{W I G}-r_{A W R}\right)
$$

Estimation of equity of companies outside of the public trading may seem to be a problem. In such a situation, estimation is performed on the basis of the listing of companies comparable to the analysed one, operating in the same industry and with known capital structure. Beta factor is calculated for them on the basis of stock exchange data and its' value is averaged; subsequently, making use of Hamada's equation which combines the value of beta factor of 
equity with the capital structure, the so-called unlevered beta is calculated, deprived of the effect of financial leverage.

The mathematical formula is as follows:

$$
\beta_{U}=\frac{\beta_{E a}}{1+\frac{D}{E} \cdot(1-T)}
$$

where:

$\beta_{U}-$ unlevered beta,

$\beta_{E a}-$ beta calculated for comparable companies.

Another step is calculation of beta of equity of an analysed company, taking the structure of its' assets into account, i.e. the so-called relevered beta, which is presented in the formula below:

$$
\beta_{E}=\beta_{U} \cdot\left(1+\frac{D}{E} \cdot(1-T)\right)
$$

Beta factor received in the manner presented above is to be subsequently used in the formula for the value of cost of equity in the CAPM.

\section{Estimation of Cost of Equity of Fuel and Energy Concern via CAPM Exemplified by Tauron Group and PGE}

Equity is an important source to finance the operation of fuel and energy concerns due to the fact that extraction activity is characterised by the presence of expenses with a significant degree of risk (research work, prospecting the deposit), for which it is often the only available source of financing. The most precise estimation of costs of equity is therefore an important issue from the point of view of fuel and energy concerns.

Calculation of cost of equity was made on the basis of the CAPM for two fuel and energy concerns listed on the Warsaw Stock Exchange, PGE and Tauron Polska Energia. Application of the CAPM required adoption of the following principles:

- the risk-free rate $r_{A W R}$ was adopted on the level of $3.140 \%$, as the rate announced by the Energy Regulatory Office for companies from the gas sector and operators of electric energy systems for the second quarter of 2017 ,

- the time range of stock exchange data adopted for determination of beta factor encompassed dates from 01.01.2016 to 31.05.2017,

- the rate of return from the market portfolio $r_{W I G}$ was calculated on the basis of changes in WIG in the second quarter of 2017 and amounted to $5.37 \%$,

- beta factor of equity $\beta_{E}$ was determined as the relation of co-variance to variance between changes in the rate of return from the WIG market portfolio $r_{W I G}$ and the rate of return from shares of the examined concern was determined $r_{E}$, for which the cost of capital is calculated.

Table 1. Input data of CAPM

\begin{tabular}{|l|l|}
\hline The rate of return of risk-free assets $r_{A W R}$ & $3.14 \%$ \\
\hline The rate of return of the stock exchange portfolio $r_{W I G}$ & $5.37 \%$ \\
\hline
\end{tabular}


Based on the collected data, the estimation of the cost of equity in two largest fuel and energy concerns listed at the Warsaw Stock Exchange was made. The results are presented in Table 2.

Table 2. $\beta$ factor and cost of equity of analysed companies

\begin{tabular}{|c|c|c|c|c|}
\hline Company name & Factor $\boldsymbol{\beta}_{E}$ & $\boldsymbol{r}_{\boldsymbol{A W R}}$ & $\boldsymbol{r}_{\boldsymbol{W I G}}$ & $\boldsymbol{K}_{\boldsymbol{E}}$ \\
\hline Tauron & 1.069 & $3.14 \%$ & $5.37 \%$ & $5.52 \%$ \\
\hline PGE & 0.984 & $3.14 \%$ & $5.37 \%$ & $5.33 \%$ \\
\hline
\end{tabular}

The obtained value of beta equal to 1.069 in the case of Tauron shows that the shares of this company constitute assets with risk higher than the market risk $(>1)$, whereas in the case of Polska Grupa Energetyczna (PGE), this interpretation is reverse, which means that the shares of this group are characterised by smaller risk from the market portfolio identified with the WIG index $(<1)$.

Based on the calculated values of cost of equity and balance sheet data of analysed companies, it was possible to estimate the so-called unlevered beta, devoid of the effect of financial leverage for the known capital structure, resulting from the balance sheets of analysed companies. The results are presented in Table 3.

Table 3. Unlevered beta factor of equity of analysed companies

\begin{tabular}{|c|c|c|c|}
\hline Company name & Factor $\boldsymbol{\beta}_{\boldsymbol{E}}$ & $\begin{array}{c}\text { D/E financing } \\
\text { structure factor }\end{array}$ & $\begin{array}{c}\text { Unlevered } \\
\text { beta factor } \boldsymbol{\beta}_{\boldsymbol{U}}\end{array}$ \\
\hline Tauron & 1.069 & 0.91953179 & 0.613 \\
\hline PGE & 0.984 & 0.540503 & 0.684 \\
\hline
\end{tabular}

On this basis, it was also possible to examine the changes in the level of equity of each company depending on the financing structure. To this aim, the so-called relevered beta is calculated for the examined capital structure. Dependence between the level of cost of equity and the capital structure is presented in Figure 2.

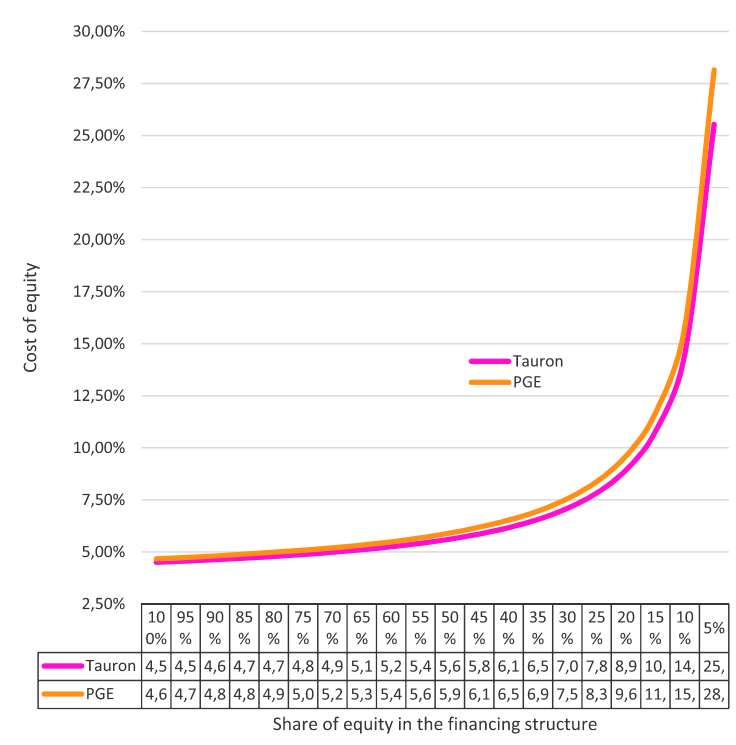

Fig. 2. Sensitivity analysis of cost of equity as a function of financing structure 
As shown by the calculations, the value of unlevered beta for PGE is higher from the value of this factor for Tauron, which results from significant differences in the structure of financing for analysed companies. This also translates to greater growth dynamics of the cost of equity, along with an increase of the share of debt in the structure of financing, which is shown by the diagram above.

On account of similar values of cost of equity in both analysed companies with respect to the financing structure currently applied by them, differences resulting from the sensitivity analysis of the cost of equity from the financing structure are slight (of a few percent), similarly to the pace of changes of this value.

\section{Conclusion}

An accurate estimation of the cost of equity in capital groups of fuel and energy sector is an important issue on account of the significance of this value in weighted average cost of capital (WACC).

There are multiple methods of estimating cost of equity, among which the CAPM is used most often in practice; it relies on designation of beta factor of a listed company, showing the dependence between the fluctuation of share rates of a given company and the market index (in Poland, usually WIG or WIG20 index).

It is possible and justified to estimate the cost of equity of holdings from the fuel and energy industry listed on the Warsaw Stock Exchange, such as Tauron and PGE, with the application of the CAPM. Determination of beta factor and the cost of equity for the abovelisted companies simultaneously allowed for performance of sensitivity analysis of their cost of equity depending on changes in the structure of financing.

The obtained results show that with respect to the current structure of financing, higher cost of equity characterises Tauron, even though differences in the level of this cost between the companies are slight. On the other hand, sensitivity analysis of the cost of equity depending on the financing structure showed a greater pace of changes and a higher level of border cost of equity for PGE. The performed analyses allowed for implementing the basic objective of the article.

Analyses presented in the article may be expanded in the future to calculation of the WACC for the described capital groups based on the hitherto equity structure and an attempt may be made at designating an optimal financing structure for determined cost levels of equity and borrowed capital.

\section{References}

1. A. Duliniec, Struktura i koszt kapitału w przedsiębiorstwie, PWN, Warszawa, (2001)

2. M. Czekała, A. Grześkowiak, Szacowanie kosztu kapitału $w$ warunkach dużej zmienności stóp zwrotu, [in:] Zarządzanie finansami w transformacji przedsiębiorstw, collective work edited by T. Jajuga and T. Słoński, Wyd. Akademii Ekonomicznej im. Oskara Langego we Wrocławiu, Wrocław, p. 83. (1999)

3. M. Kufel, Metody wyceny przedsiębiorstw, Wyd. Park, Bielsko-Biała, p. 37-38, (1992)

4. J.W. Petty, A.J. Keown, D.F. Scott, J.D. Martin, Basic Financial Management, Englewood Cliffs, p. 267. (1993)

5. R. Ranosz, A. Kustra, Koszt kapitału własnego spółek górniczych w Polsce, [in:] Zeszyty Naukowe Uniwersytetu Szczecińskiego Finanse, Rynki Finansowe, Ubezpieczenia, No. 60, No. 761, (2013) 
6. K.S. Rao Ramesh, Financial Management, Concepts and Applications, South-Western College Publishing, Cincinnati, (1995)

7. M. Sierpińska, T. Jachna, Ocena przedsiębiorstwa wedtug standardów światowych, PWN, Warsaw, p. 246, (2003)

8. P. Szczepankowski, Wycena i zarządzanie wartościa przedsiębiorstwa, Wydawnictwa Naukowe PWN, Warsaw, (2007)

9. J.F. Weston, T.E. Copeland, Managerial Financial Management, p. 438. (1988) 